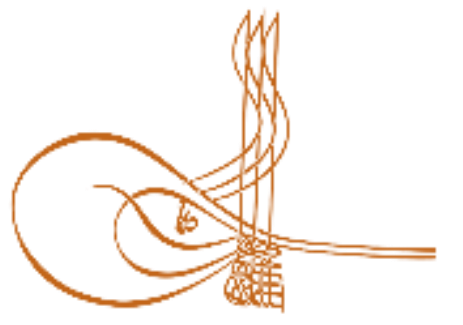

www.turkishstudies.net/turkishstudies
Turkish Studies

eISSN: $1308-2140$

Research Article / Araştırma Makalesi

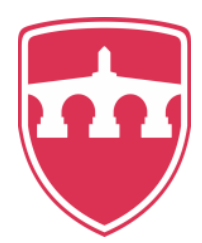

INTERNATIONAL

BALKAN

UNIVERSITY

Sponsored by IBU

\title{
Üniversite Öğrencilerinin Spora Yönelik Tutumlarının Benlik Saygısı Düzeyine Etkisinin İncelenmesi (Doğu Marmara Bölgesi Üniversiteleri Örneği)
}

\author{
Analysing The Effect of University Students 'Attitudes Towards Sports on Self-Esteem Level \\ (Eastern Marmara Region Universities Sample)
}

\author{
Ülkü Çoban ${ }^{*}$ - Betül Bayazıt ${ }^{* *}-$ Levent Atalı ${ }^{* * *}-$ Merve Uca $^{* * * *}$
}

\begin{abstract}
In this study; The aim of this study is to determine the effects of attitudes of students studying in different programs in East Marmara Region Universities (Kocaeli University, Düzce University, Sakarya University, Abant İzzet Baysal University, Yalova University) on their self-esteemi. This research was carried out on 933 undergraduate and associate students studying in different departments of 5 foundation universities in East Marmara region. The effect of attitudes of the university students, who constitute sportive attitude the study group, on the self-esteem, were investigated. In the research sample, the effect of the attitudes of the university students, who form the study group, on their self-esteem and their levels were examined. Descriptive statistical methods (Number, Percentage, Arithmetic Mean, Standard deviation) were used in the evaluation of the study data. "T-test", ANOVA, "Post-Hoc" uk Tukey "and" Dunnett T3 "test were applied. Data analysis was performed in SPSS 20.0 package program. Data analysis was evaluated at 95\% confidence interval and $p$ $<0.05$ significance level. First of all the sample group, education level, gender, age, sportive attitude, selfesteem were not statistically significant. It was found that it had a positive and significant relationship in almost all parameters $(\mathrm{p}<0.05)$. There was no significant difference in gender, marital status and education levels of
\end{abstract}

\footnotetext{
* Dr. Öğr. Üyesi, Yalova Üniversitesi, Spor Bilimleri Fakültesi, Spor Yöneticiliği Bölümü Asst. Prof. Dr., Yalova University Faculty of Sports Science Department of Sport Managment ORCID 0000-0001-8308-7655

ulku.coban@yalova.edu.tr

** Doç. Dr., Kocaeli Üniversitesi, Spor Bilimleri Fakültesi, Rekreasyon Bölümü

Assoc. Prof. Dr., Kocaeli University, Faculty of Sports Sciences, Department of Recreation ORCID 0000-0003-3547-2035

betul.bayazit@kocaeli.edu.tr

**** Doç. Dr., Kocaeli Üniversitesi, Spor Bilimleri Fakültesi, Spor Yöneticiliği Bölümü Assoc. Prof. Dr., Kocaeli University, Faculty of Sports Sciences, Department of Recreation ORCID 0000-0002-2035-8523

levent.atal1@kocaeli.edu.tr

***** Dr. Öğr. Üyesi, İstanbul Aydın Üniversitesi, Spor Bilimleri Fakültesi, Beden Eğitimi ve Spor Bölümü Asst. Prof. Dr., Ístanbul Aydin University, Faculty of Sports Science/Department of Physical Education and Sport ORCID 0000-0003-3325-8828

merveuca@aydin.edu.tr
}

Cite as/ Atıf: Çoban, Ü., Bayazıt B., Atalı, L., Uca, M. (2020). Üniversite öğrencilerinin spora yönelik tutumlarının benlik saygısı düzeyine etkisinin incelenmesi (Doğu Marmara Bölgesi Üniversiteleri Örneği), Turkish Studies, 15(1), 105-116. https://dx.doi.org/10.29228/TurkishStudies.39954

Received/Geliş: 29 November/Kasım 2019

Accepted/Kabul: 25 February/Şubat 2020

Checked by plagiarism software

Copyright $\mathbb{C}$ MDE, Turkey 
sports attitudes. At the level of self-esteem of the sportive attitude, positive self-efficacy $(\mathrm{p}>0,05)$. In the negative direction, explain significantly.

Structured Abstract: In this study, it was aimed to analyse the effect of sports-oriented attitudes of students in different programs in Eastern Marmara region universities (Kocaeli University, Düzce University, Sakarya University, Bolu Abant Izzet Baysal University, Yalova University) on self-esteem level. The research was conducted on a total of 933 undergraduate and associate degree students who are studying in different departments of 5 state universities in the Eastern Marmara region. In the research sample, the effect of the attitudes of the university students who made up the study group towards sport on their self-esteem was analysed.

Physical education and sports are often perceived as the equivalent of physical activity habits. However, sports provide the individual's body and mental health, the formation of personality and the development of character traits, as well as the individual's knowledge, skills and ability to improve harmony with the environment. The attitude is an important Notion of psychology. There is a general consensus that attitude as a word meaning represents the assessment of a psychological object in dimensions of self-nature, such as good-bad, harmful-beneficial, pleasant-unpleasant, and ordinary-unusual. İn view the role of university students in the formation of cultural and social norms, the importance of these students ' sporting activity habits increases. Although the effects of regular sports activities on health have been acknowledged, the relationship between attitude towards sport and self-esteem has not been clearly explained. Not enough research has been done on attitudes towards sport and levels of self-esteem in general. It is clear that sports activities are one of the most important tools for strengthening the communication skills and socialization of children and young people. The findings that reveal that sports are effective in the individual's personality development and adaptation process to society have been procured, as well as some negative effects have been revealed in the research. It is thought that the attitudes of university students towards sports have a positive effect on their quality of life and academic achievement by increasing their sense of self-esteem.

Many definitions of the Notion, self, self esteem, body image have been made in the studies. Although there are little differences in the definitions, in the most general sense, the Notion of self can be defined as the person's descriptions of himself or herself. Self-esteem, on the other hand, is defined as the evaluations that the person makes for these descriptions. In other words, the notion of self includes the thoughts and perceptions one has about oneself, while self-esteem involves one's feelings towards one's self. Self-acceptance is a term for whether or to what extent an individual accepts the characteristics that he or she adopts as part of his or her personality as a result of realizing the aspects that he or she can not achieve to his or her ideal self. In other words, self-acceptance is whether the individual is satisfied with his or her characteristics or to what degree he or she is satisfied (Videbeck 2001). In our study, the findings of the analysis carried out to demonstrate the power of university students to express their self-esteem indicate that sporting attitude explains self-esteem at a significant level. $(\mathrm{p}<0,01 ; \mathrm{p}<0,05)$.

Keywords: University Student, Attitude Towards Sports, Self-Esteem

Öz: Bu araştırmada; Doğu Marmara Bölgesi Üniversitelerinde (Kocaeli Üniversitesi, Düzce Üniversitesi, Sakarya Üniversitesi, Bolu Abant İzzet Baysal Üniversitesi, Yalova Üniversitesi) farklı programlarda öğrenim gören öğrencilerin spora yönelik tutumlarının benlik saygısı düzeyine etkisinin incelenmesi amaçlanmıştır. Araştırma, Doğu Marmara bölgesin de yer alan 5 Devlet üniversitesinin farklı bölümlerinde öğrenim görmekte olan toplam 933 lisans ve ön lisans öğrencileri üzerinde gerçekleştirilmiştir. Araştırma örneklemin de, çalışma grubunu oluşturan üniversite öğrencilerinin spora yönelik tutumlarının benlik saygısına etkisi incelenmiştir. Çalışma verileri değerlendirilirken tanımlayıcı istatistiksel metodları (Sayı, Yüzde, Aritmetik Ortalama, Standart sapma) kullanılmıştır. "t-testi", ANOVA, "Post-Hoc" "Tukey" ve "Dunnett T3" testi uygulanmıştır. Verilerin çözümlemesi SPSS 20.0 paket programında yapılmıştır. Verilerin analizi \%95 güven aralığında, $\mathrm{p}<0.05$ anlamlılık düzeyinde değerlendirilmiştir. Çalışma grubunun eğitim aldığı üniversite, eğitim düzeyi, cinsiyet, yaş, sportif tutum, benlik saygısı, puan ortalamaları, her ne kadar istatistiksel açıdan anlamlı bir fark olmasa da, hemen hemen tüm parametrelerde $(\mathrm{p}<0,05)$ düzeyde pozitif yönde ve anlamlı bir ilişkiye sahip olduğu bulunmuştur. Spora yönelik tutumun cinsiyet, medeni durum ve eğitim düzeyleri açısından anlamlı bir 
farklılık bulunmamıştır $(\mathrm{p}>0,05)$. Sportif tutumun benlik saygısı düzeyini negatif yönde açıkladığını göstermektedir $(\mathrm{p}>0,05)$.

Anahtar Kelimeler: Üniversite Öğrencisi, Spora Yönelik Tutum, Benlik Saygısı,

\section{Giriş}

Beden eğitimi ve spor genellikle fiziksel aktivite alışkanlığının karşı1lığı olarak algılanmaktadır (Koca ve Aşcı, 2004). Oysaki spor bireyin beden ve ruh sağlığını, kişiliğin oluşumunu ve karakter özelliklerinin gelişimini sağlamanın yanında bireye bilgi, beceri ve yetenek kazandırarak çevreyle olan uyumunu geliştirmeyi sağlar (Varol ve ark, 2017). Tutum (attitude) kavramı ise psikolojinin önemli bir kavramıdır. Kelime anlamı olarak tutumun, iyi-kötü, zararlıfaydalı, hoş-nahoş ve olağan-olağandışı gibi öz-nitelik boyutlarında psikolojik bir nesnenin değerlendirmesini temsil ettiği konusunda genel bir fikir birliği vardır (Ajzen 2001). Bir başka deyişle tutum, bireyin karşılaştığı çıkan bir uyaran (nesne, durum, olay) karşısında onunla ilgili olumlu veya olumsuz değerlendirme yapmasıdır. Tutumlar, bilişsel, etkisel ve davranışsal olmak üzere üç grupta incelenir. Bilişsel tutum düşünceleri, etkisel tutum duyguları ve davranışsal tutumlar davranışları kapsamaktadır (Gerrig ve diğ. 2013). Üniversite öğrencilerinin kültürel ve sosyal normların oluşumundaki rolleri göz önüne alındığında bu öğrencilerin sahip oldukları sportif aktivite alışkanlıklarının önemi artmaktadır. Düzenli olarak yapılan spor aktivitelerinin sağlık üzerindeki etkileri kabul edilmekle birlikte spora yönelik tutum ile benlik saygısı arasındaki ilişki net bir şekilde açıklanamamıştır. Genel olarak spora yönelik tutum ile benlik saygısı düzeylerine ilişkin yeteri kadar araştırma yapılmadığı görülmüştür. Sportif aktivitelerin çocuk ve genç bireylerin iletişim becerilerinin güçlenmesinde ve sosyalleşmesinde en önemli araçlardan biri olduğu açıtır. Sporun bireyin kişilik gelişiminde ve topluma adaptasyon sürecinde etkili olduğunu ortaya koyan bulgular elde edildiği gibi olumsuz bazı etkiler yarattığ 1 da araştırmalarda ortaya konulmuştur. Üniversite öğrencilerinin spora yönelik tutumlarının benlik saygısı duygularını arttırarak yaşam kalitesini ve akademik başarı düzeylerine de pozitif yönde bir etki yaratığı düşünülmektedir.

Alan yazın incelendiğinde üniversite öğrencilerinin spora yönelik görüşleri ile ilgili çalışma bulmakta güçlük çekilirken; ilkokul, ortaokul ve lise öğrencilerinin beden eğitimi ve spor dersine yönelik tutumlarını incelemiş olan çalışmalar bulunabilmektedir (Güllü 2009, Çetin 2007, Taşğın ve Tekin 2009, Şişko ve Demirhan 2002). Yapılan çalışmalarda benlik kavramı, benlik saygısı, beden imajı kavramlarının birçok tanımı yapıldığı görülmektedir. Yapılan tanımlamalarda küçük farklılıklar olmasına rağmen en genel anlamda; benlik kavramı, kişinin, kendine yönelik olarak yaptığı betimlemeleri olarak tanımlanabilir. Benlik saygısı ise, kişinin bu betimlemeleri için yaptığı değerlendirmeler olarak tanımlanmaktadır. Bir başka deyişle, benlik kavramı, kişinin kendisi hakkında sahip olduğu düşünce ve algılamaları içerirken, benlik saygısı kişinin kendisine yönelik duyguların içermektedir. Kendini kabul ise bireyin ideal benliğine ulaşamadığı yanlarını fark etmesi sonucu, kişiliğinin parçası olarak benimsediği özellikleri kabul edip etmemesine ya da ne ölçüde kabul ettiğine ilişkin bir terimdir. Başka bir deyişle kendini kabul, bireyin kendi özelliklerinden memnun olup olmaması ya da ne derece memnun olduğudur (Videbeck 2001) Benlik saygisının iki temel kaynağ 1 vardır: Birincisi, bireyin çeşitli alanlarda başarı ve başarısızlıklarını içeren kendi deneyimleridir. İkincisi ise bireyin hayatında önemli rol oynayan kişilerden alınan geribildirimlerdir. Benlik saygısının bu iki kaynağı birbirinden bağımsızdır. Örneğin birey, diğer insanların kendisine olan ilgisinden şüphe duyarken; doğru şeyler yapma konusundaki yeteneğinden emin olabilmektedir (Orth ve diğ. 2015). Hareket, beden eğitimi spor etkinlikleri gibi fiziksel ve psikomotor temelli aktiviteler, kişinin, özellikle ergenin benlik tasarımında, kendisini olumlu algılaması açısından önem taşımaktadır. Bireyin bedenini tanıması, yeteneklerinin farkına varması, yeterlilik duygusu oluşturması, duygu ve düşüncelerinin ifade etmesi ve davranışa dönüştürmesi gibi açılımlar, onun dinamik bir görüntü ve tutum oluşturmasını sağlamaktadır. Kişi kendisine karşı olumlu tutum 
oluştururken, etkinlikte bulunduğu çevrenin ve arkadaşlarının olumlu tutumları kendisini sevmesi, önemsemesi ve değerli görmesini sağlar. Bu da, benlik saygısının yükselmesi anlamına gelir. Benlik saygısı yüksek olan bireylerde yaşama sevinci ve iyimserlik artar.

\section{Yöntem}

\section{Araştırmanın Modeli}

Bu araştırma "tarama modeli" olarak tasarlanmıştır. "Tarama modelleri, geçmişte ya da halen var olan bir durumu var olduğu şekilde betimlemeyi amaçlayan araştırma yaklaşımlarıdır. Araştırmaya konu olan olay, birey ya da nesne, kendi koşulları içinde ve olduğu gibi tanımlanmaya çalış11ır. Onları herhangi bir şekilde değiştirme, etkileme çabası gösterilmez" (Karasar, 2009,). Araştırmada spora yönelik tutumlarının benlik saygısı, düzeylerine belirleyici etkileri ortaya konulacaktır. Araştırmanın bağımsız değişkenini spora yönelik tutum; bağımlı değişkeni ise benlik saygısı, oluşturmaktadır. Bu çalışmanın etik kurulu, Kocaeli Üniversitesi Girişimsel Olmayan Klinik Araştırmalar Etik Kurulu'nun KÜ GOKAEK 19.07.2017 tarihli ve 2017/10.15 no'lu raporu ile alınmıştır. Araştırmanın amacı, hedefleri ve yöntemi gönüllüler açısından beklenen yarar ve riskler dikkate alınarak değerlendirilerek ve araştırmanın ilgili protokol doğrultusunda belirtilen merkezlerde yürütülmesi etik açıdan uygun bulunmuştur.

\section{Evren ve Örneklem}

Çalışmanın evrenini Doğu Marmara bölgesindeki beş devlet üniversitesin de öğrenim gören öğrenciler oluşturmaktadır. Doğu Marmara bölgesinde devlet üniversitesi olarak Kocaeli Üniversitesi toplam öğrenci sayıs1 81.000 üzeri; Düzce Üniversitesi toplam öğrenci sayıs1 29.477; Sakarya Üniversitesi toplam öğrenci sayıs1 93.464; Yalova Üniversitesi toplam öğrenci sayıs1 14.816; Abant İzzet Baysal Üniversitesi toplam öğrenci sayıs1 32.906; dır. Örneklemi Doğu Marmara bölgesinde yer alan beş üniversiteden 933 öğrenci oluşturmaktadır.

\section{Veri Toplama Araçları}

Araştırmada veri toplama aracı olarak kişisel bilgi formu, spora yönelik tutum ölçeği, benlik saygısı ölçeği, uygulanmıştır. Araştırmada kullanılan "Spora Yönelik Tutum Ölçeği (SYTÖ)" Şentürk (2014) tarafından geliştirilmiştir. Toplam 25 madde ve 3 alt boyuttan (spora ilgi duyma, sporla yaşama ve aktif spor yapma) oluşmaktadır. SYTÖ 5'li likert tipi “Tamamen Katılıyorum (5), Katıliyorum (4), Kararsızım (3), Katılmıyorum (2), Kesinlikle Katılmıyorum (1)" şeklinde derecelendirilmektedir. Ölçekten alınabilecek minimum puan 25 ve maksimum puan 125 'tir. Puanın yüksekliği, spora yönelik tutumun yüksekliğine işaret etmektedir. Stanley Coopersmith tarafından 1986 yılında hazırlanan benlik saygısı ölçeği, bireyin kendisi ile ilgili tutumunu değerlendirmede kullanılabilen, çeşitli yaş gruplarına, özellikle yetişkinlere uygulanabilecek şekilde geliştirilmiş bir ölçektir. Ölçek " 25 ifadeden oluşmaktadır. Kısa form için bir bireyin benlik saygısı puanı maksimum 25 olabilir ve ölçekten alınan puan arttıkça benlik saygısı da artmaktadır (Oktan ve Şahin, 2010).

\section{Verilerin İstatistiksel Analizi}

Çalışmada elde edilen bulgular değerlendirilirken, istatistiksel analizler için SPSS (Statistical Package for Social Sciences) for Windows 20.0 programı kullanılmıştır. Çalışma verileri değerlendirilirken tanımlayıcı istatistiksel metotları (Sayı, Yüzde, Aritmetik Ortalama, Standart sapma) kullanılmıştır. Hipotez testleri olarak; iki bağımsız örneklem grubu ortalamaları açısından farklı olup olmadığını anlamak için "t-testi", grup sayısının ikiden fazla olduğu durumlarda ise "ANOVA" kullanılmıştır. ANOVA testinde farklılığın hangi gruplar arasında olduğunu ortaya koymak üzere "Post-Hoc" testlerinden varyans eşitliği durumuna göre "Tukey" veya "Dunnett T3" testleri uygulanmıştır. Bağımlı değişkenin bağımsız değişken ile arasındaki ilişkiyi, ilişkinin şiddeti ve yönü açısından analizlemek için bu çalışmada "Regresyon Analizi" yapılmıştır. Sonuçlar \% 95 güven aralığında, anlamlılık $\mathrm{p}<0,05$ düzeyinde değerlendirilmiştir. Bu amaç doğrultusunda şu 
sorulara yanıt aranmaya çalışıııışıı; Doğu Marmara Bölgesi Üniversitelerinin farklı programlarında öğrenim gören öğrencilerde; Spora yönelik tutum benlik saygısına nasıl bir etki yaratmıştır. Araştırma 2017-2018 eğitim-öğretim yılında farklı programlarda öğrenim gören 386's1 erkek 547'si kadın olmak üzere toplam 933 gönüllü öğrenci ile sınırlandırılmıştır.

\section{Bulgular}

\section{Tanımlayıcı İstatistiklere (Ölçütlere) İlişsin Bulgular}

Tablo 1: Örneklem Grubunun Yaşlarına İlişkin Bulgular

\begin{tabular}{|l|l|l|}
\hline \multirow{2}{*}{} & & \\
\hline Yaş Grubu & & \\
\hline 18 yaş ve altı & Frekans & Yüzde (\%) \\
\hline 19 yaş & 55 & 5,9 \\
\hline 20 yaş & 145 & 15,5 \\
\hline 21 yaş & 200 & 21,4 \\
\hline 22 yaş & 190 & 20,4 \\
\hline 23 yaş ve üzeri & 150 & 16,1 \\
\hline Toplam & 193 & 20,7 \\
\hline
\end{tabular}

Örneklem grubunun yaşlarına göre dağ 11 mı tablo.1'de incelenmiştir. Buna göre araştırmaya katılan öğrencilerin 4'nün $(\% 0,4) 17,49$ 'unun $(\% 5,3) 18,145$ 'inin $(\% 15,5) 19,200$ 'ünün $(\% 21,4)$ 20, 190'1nın (\%20,4) 21, 150'sinin (\%16,1) 22, 83'ünün (\%8,9) 23, 56'sının (\%6) 24, 31 'inin $(\% 3,3)$ 25 yaşında ve 23 'ünün $(\% 2,5) 26$ yaş ve üzeri olduğu görülmektedir.

Tablo 2: Örneklem Grubunun Spor Yaptığı Sürelere İlişkin Bulgular

\begin{tabular}{|l|l|l|l|}
\hline Spor Yaptı̆̆ Süre (Y1l) & Frekans & Yüzde (\%) & Kümülatif (\%) \\
\hline Hiç & 313 & 33,5 & 100,0 \\
\hline 1 & 240 & 25,7 & 66,5 \\
\hline 2 & 90 & 9,6 & 40,7 \\
\hline 3 & 50 & 5,4 & 31,1 \\
\hline 4 & 44 & 4,7 & 25,7 \\
\hline 5 & 47 & 5,0 & 21,0 \\
\hline 6 & 29 & 3,1 & 16,0 \\
\hline 7 & 18 & 1,9 & 12,9 \\
\hline 8 & 20 & 2,1 & 10,9 \\
\hline 9 & 14 & 1,5 & 8,8 \\
\hline 10 & 40 & 4,3 & 7,3 \\
\hline 11 & 2 &, 2 & 3,0 \\
\hline 12 & 7 &, 8 & 2,8 \\
\hline 13 & 3 &, 3 & 2,0 \\
\hline 14 & 2 &, 2 & 1,7 \\
\hline 15 & 11 & 1,2 & 1,5 \\
\hline 16 & 1 &, 1 & 0,3 \\
\hline 17 & 1 &, 1 & 0,2 \\
\hline 20 & 1 &, 1 & 0,1 \\
\hline Toplam & 933 & 100,0 & \\
\hline
\end{tabular}




\begin{tabular}{|l|l|l|}
\hline Spor Yaptıkları Yıl & Frekans & Yüzde \\
\hline Hiç & & \\
\hline 1 yıl & 313 & 33,5 \\
\hline 2 yıl & 240 & 25,7 \\
\hline 3 yıl & 90 & 9,6 \\
\hline 4 yıl & 50 & 5,4 \\
\hline 5 yil ve üzeri & 44 & 4,7 \\
\hline Toplam & 196 & 21,0 \\
\hline
\end{tabular}

Örneklem grubunun spor yaptığı sürelere göre dağılımı tablo.2'de incelenmiştir. Buna göre araştırmaya katılan öğrencilerin 313'ü $(\% 33,5)$ hiç spor yapmamıştır. Örneklem grubumuzun 240 '1 $(\% 25,7) 1$ y1l, 90’ı (\%9,6) 2 yıl, 50'si $(\% 5,4) 3$ yıl, 44'ü $(\% 4,7) 4$ yıl, 47'si (\%5) 5 yıl, 29'u $(\% 3,1)$ 6 yıl, 18'i (\%1,9) 7 y1l, 20'si $(\% 2,1) 8$ yıl, 14'ü $(\% 1,5) 9$ yıl, 40'ı $(\% 4,3) 10$ y1l, 29’u $(\% 3,0)$ ise 11 y1l ve 11 y1ldan daha uzun süre ile spor yapmıştır. Örneklemimizde en uzun spor yapan 20 yıl ise 1 kişidir, onu takip eden 17 ve 16 yıl ile yine 1'er kişidir.

Tablo 3: Örneklem Grubunun Cinsiyetlerine İlişkin Bulgular

\begin{tabular}{|l|l|l|}
\hline Cinsiyet & Frekans & Yüzde (\%) \\
\hline Erkek & 386 & 41,4 \\
\hline Kadın & 547 & 58,6 \\
\hline Toplam & 933 & 100,0 \\
\hline
\end{tabular}

Örneklem grubunun cinsiyetlerine göre dağılımı çizelge 9.3'te incelenmiştir. Buna göre araştırmaya katılan öğrencilerin 386'sı (\% 41,4) erkek, 547'si (\% 58,6) kadındır.

Tablo 4: Örneklem Grubunun Medeni Durumlarına İlişkin Bulgular

\begin{tabular}{|l|l|l|}
\hline Medeni Durum & Frekans & Yüzde (\%) \\
\hline Evli & 22 & 2,4 \\
\hline Bekâr & 910 & 97,6 \\
\hline Toplam & 932 & 100,0 \\
\hline
\end{tabular}

Örneklem grubunun medeni durumlarına göre dağılımı çizelge 9.4'da incelenmiştir. Buna göre araştırmaya katılan öğrencilerin 22'si (\% 2,4) evli, 910’u ise (\% 97,6) bekârdır.

Tablo 5: Örneklem Grubunun Okuduğu Üniversiteye İlişkin Bulgular

\begin{tabular}{|l|l|l|}
\hline Üniversite & Frekans & Yüzde (\%) \\
\hline Bolu & 201 & 21,5 \\
\hline Düzce & 140 & 15,0 \\
\hline Kocaeli & 182 & 19,5 \\
\hline Sakarya & 118 & 12,6 \\
\hline Yalova & 292 & 31,3 \\
\hline Toplam & 933 & 100,0 \\
\hline
\end{tabular}

Örneklem grubunun okumakta olduğu üniversitelere göre dağılımı tablo 5 'te incelenmiştir. Buna göre araştırmaya katılan öğrencilerin 201'i (\% 21,5) Bolu Üniversitesi’nde, 140 '1 (\%15) Düzce 
Üniversitesi'nde, 182'si (\% 19,5) Kocaeli Üniversitesi’nde, 118'i (\% 12,6) Sakarya Üniversitesi’nde, 292'si (\% 31,3) Yalova Üniversitesi'nde eğitim yaşantılarına devam etmektedir.

Tablo 6: Örneklem Grubunun Eğitim Düzeyine İlişkin Bulgular

\begin{tabular}{|l|l|l|}
\hline Eğitim Düzeyi & Frekans & Yüzde (\%) \\
\hline Önlisans & 34 & 3,7 \\
\hline Lisans & 887 & 95,4 \\
\hline Yüksek Lisans & 9 & 1,0 \\
\hline Toplam & 930 & 100,0 \\
\hline
\end{tabular}

Örneklem grubunun öğrenim görmekte olduğu eğitim düzeylerine göre dağılımı tablo.6'da incelenmiştir. Buna göre araştırmaya katılan öğrencilerin 34'ü (\% 3,7) ön lisans düzeyinde, 887'si $(\% 95,4)$ lisans düzeyinde, 9’u (\% 1) yüksek lisans düzeyinde öğrenim görmektedir.

Tablo 7: Örneklem Grubunun Kendilerinin ve Ailelerinin Ekonomik Gelir Düzeylerine İlişkin Bulgular

\begin{tabular}{|l|l|l|}
\hline Gelir Düzeyi & Frekans & Yüzde (\%) \\
\hline 0-500 TL (en düşük) & 36 & 3,9 \\
\hline 501-1500 TL(düşük) & 185 & 19,9 \\
\hline 1501-2500 TL(orta) & 360 & 38,7 \\
\hline 2501-5000 TL(yüksek) & 277 & 29,8 \\
\hline 5001 TL ve üstü(en yüksek) & 73 & 7,8 \\
\hline Toplam & 931 & 100,0 \\
\hline
\end{tabular}

Örneklem grubunun kendilerinin ve ailelerinin ekonomik gelir düzeylerine göre dağ 11 ımı tablo 7.'de incelenmiştir. Buna göre araştırmaya katılan öğrencilerin 3'ünün (\% 3,9) ekonomik düzeylerinin 0-500 TL (en düşük), 185'inin (\% 19,9) 501-1500 TL (düşük), 360'inın (\% 38,7) 15012500 TL (orta), 277'sinin (\% 29,8) 2501-5000 TL (yüksek), 73'ünün (\% 7,8) 5001 TL ve üstü ekonomik düzeye sahip oldukları görülmektedir.

Tablo 8: Örneklem Grubunun Genel Olarak Kendi Ekonomik Gelir Düzeyinden Memnun Olma Durumlarına İlişskin Bulgular

\begin{tabular}{|l|l|l|}
\hline Memnuniyet & Frekans & Yüzde (\%) \\
\hline Hiç değil & 61 & 6,6 \\
\hline Değil & 115 & 12,4 \\
\hline Kismen memnun & 326 & 35,0 \\
\hline Memnun & 386 & 41,5 \\
\hline Çok memnun & 43 & 4,6 \\
\hline Toplam & 931 & 100,0 \\
\hline
\end{tabular}

Örneklem grubunun genel olarak kendi ekonomik gelir düzeyinden memnun olma durumlarına göre dağılımı tablo 8 'de incelenmiştir. Buna göre araştırmaya katılan öğrencilerin 61'inin (\% 6,6) hiç memnun olmadığı, 115 'inin (\% 12,4) memnun olmadığ, 326 'sının (\% 35) kısmen memnun olduğu, 386'sının (\% 41,5) memnun olduğu, 43'ünün $(\% 4,6)$ çok memnun olduğu görülmektedir. 
Tablo 9: Örneklem Grubunun Gelir Getirici Bir İş Olarak Sporu Yeterli Görme Durumlarına İlişkin Bulgular

\begin{tabular}{|l|l|l|}
\hline & Frekans & Yüzde (\%) \\
\hline Hiç değil & 122 & 13,1 \\
\hline Değil & 270 & 29,0 \\
\hline Kısmen yeterli & 353 & 37,9 \\
\hline Yeterli & 156 & 16,7 \\
\hline Çok Yeterli & 31 & 3,3 \\
\hline Toplam & 932 & 100,0 \\
\hline
\end{tabular}

Örneklem grubunun gelir getirici bir iş olarak sporu yeterli görme durumlarına göre dağılımı tablo 9 da incelenmiştir. Buna göre araştırmaya katılan öğrencilerin 112'sinin (\% 13,1) hiç yeterli görmediği, 270'inin (\% 29) yeterli görmediği, 353'ünün (\% 37,9) kısmen yeterli gördüğü, 156'sının $(\%$ 16,7) yeterli gördüğü, 31 'inin çok yeterli gördüğü görülmektedir.

Tablo 10: Örneklem Grubunun Başarı Düzeylerine İlişsin Bulgular

\begin{tabular}{|l|l|l|}
\hline Başarı Düzeyi & Frekans & Yüzde (\%) \\
\hline Başarısız Öğrenci & 65 & 7,0 \\
\hline Başarılı Öğrenci & 547 & 58,6 \\
\hline Onur Öğrencisi & 216 & 23,2 \\
\hline Yüksek Onur Öğrencisi & 105 & 11,3 \\
\hline Toplam & 933 & 100 \\
\hline
\end{tabular}

Örneklem grubunun başarı düzeylerine göre dağılımı tablo 10 'da incelenmiştir. Buna göre araştırmaya katılan öğrencilerin 65 'inin (\% 7) Başarısız Öğrenci, 547'sinin (\% 58,6) Başarılı Öğrenci, 216’sının (\% 23,2) Onur Öğrencisi, 105 'inin (\% 11,3) Yüksek Onur Öğrencisi olduğu görülmektedir.

Tablo 11: Araştırmaya Katılanların Sportif Tutkunluk ve Benlik Saygısı Düzeyleri Arasındaki İlisskiler (pearsoncorelation analizi)

\begin{tabular}{|l|l|l|l|}
\hline \multicolumn{2}{|c|}{} & Spora Yönelik Tutum & Benlik Saygis1 \\
\hline \multirow{3}{*}{ Spora Yönelik Tutum } & $\mathrm{r}$ & 1 & \\
\cline { 2 - 4 } & $\mathrm{p}(2$-tailed) & & \\
\cline { 2 - 4 } & $\mathrm{n}$ & 933 & 1 \\
\cline { 2 - 4 } & $\mathrm{r}$ &, $150^{* *}$ & 933 \\
\cline { 2 - 4 } & $\mathrm{p}(2$-tailed) &, 000 & \\
\hline
\end{tabular}

Araştırmaya katılan öğrencilerin sportif tutkunluk düzeyleri ile benlik saygısı $\left(\mathrm{r}=150^{* *}\right)$ arasında 0,001 anlamlılık düzeyinde pozitif korelasyon bulunmuştur. Bu sonuçlara göre, öğrencilerin sportif tutkunluk düzeyleri benlik saygısı düzeylerini artırmaktadır.

\section{Araştırma Modeline İlişkin Bulgular}

Tablo 12: Üniversite Öğrencilerinin Sportif Tutumları ve Benlik Saygılarını Açılama Gücü

\begin{tabular}{|l|l|l|l|l|l|l|l|l|l|}
\hline Model & $\mathrm{r}$ & $\mathrm{r}^{2}$ & $\mathrm{r}^{2}$ & $\mathrm{f}$ & $\mathrm{p}$ & Std. Hata & $\beta$ & $\mathrm{t}$ & $\mathrm{p}$ \\
\hline Sportif Tutum &, $199^{\mathrm{a}}$ & 0,039 & 0,038 & 38,26 &, $000^{\mathrm{b}}$ & 0,03 & $-0,199$ & $-6,185$ & $0,000^{*}$ \\
\hline
\end{tabular}

$* \mathrm{p}<0,05$

Üniversite öğrencilerinin sportif tutumlarının, benlik saygılarını açıklama gücünü tablo 12 de verilmiştir. Tablo 12 incelendiğinde hesaplanan $t$ değeri, sportif tutumun benlik saygısını anlamlı 
düzeyde açıkladığ 1 göstermektedir. Kısmi korelasyon katsayısına ( $\beta$ ) bakıldığında sportif tutumun benlik saygısı ile 0,199 düzeyinde negatif yönde ve anlamlı bir ilişkiye sahip olduğu bulunmuştur.

\section{Tartışma ve Sonuç}

$\mathrm{Bu}$ çalışma farklı bölümlerde öğrenim gören üniversite öğrencilerinin spora yönelik tutumları ile benlik saygısı arasında bir ilişki olup olmadığını belirlemeye yönelik yapılmıştır. Yapmış olduğumuz çalışmada üniversite öğrencilerinin sportif tutumlarının, benlik saygılarını açıklama gücünü ortaya koymak amacıyla yapılan analize ilişkin bulgular sportif tutumun benlik saygısını anlamlı düzeyde açıkladığını göstermektedir $(p<0,01 ; p<0,05)$. Bu sonuç yapılmış olan bazı araştırmadaki sonuçlar ile paralellik göstermektedir.

Karaman ve diğ. (2012) yapmış oldukları Spor Yapan ve Yapmayan 10-12 Yaş Grubu Çocuklarda Benlik Saygısının İncelenmesi adlı çalışmada133 kişiden oluşan spor yapan ve spor yapmayan grupların benlik saygıları düzeylerinde anlamlı bir faklılık bulunmuştur. Bu araştırma sonucuna göre; bu dönem (10-12 yaş) çocuklardan spora katılanların katılmayanlara oranla kendilik algılamalarının daha olumlu ve bu farkın anlamlı olduğu görülmektedir. Benlik saygısının yüksek olmasının, genel olarak bireyin kendisine ve diğer insanlara karşı daha güvenli, kişilerarası ilişkilerini daha sağlıklı ve doyurucu, genel anlamda uyumunu artırıcı yönde etkide bulunduğu bilinmektedir (Aşç1 1999, Gün 2006, İçten ve diğ. 2006, Weinberg ve Gould 2007). Bu sonuç mevcut araştırmadaki sonuç ile paralellik göstermektedir.

Çalışmada Doğu Marmara bölgesinde yer alan beş devlet Üniversitesinde (Kocaeli Üniversitesi, Sakarya Üniversitesi, Düzce Üniversitesi, Bolu Abant İzzet Baysal Üniversitesi ve Yalova Üniversitesi) öğrenim görmekte olan 933 öğrencinin spora yönelik tutumlarının cinsiyet, spor yaptıkları yıl miktarı, medeni durumları, eğitim aldıkları üniversiteler, ailenin ekonomik gelir düzeyleri, benlik saygıları, değişkenleri açısından incelenmiş olup spora yönelik tutum düzeyleri arasında anlamlı bir farklılık olduğu tespit edilmiştir $(\mathrm{p}<0,05)$. Araştırmaya katılan öğrencilerin cinsiyet değişkenine göre ölçeklerin genelinden alınan toplam puanların ortalamalarına bakıldığında kadın öğrencilerin spora yönelik tutum puanlarının erkek öğrencilerin spora yönelik tutum puanlarından daha yüksek olduğu gözlenmiştir $(\mathrm{p}>0.05)$. Alan yazında yapılan bazı çalışmalar da bu analiz sonucunu destekler şekildedir.

Yazıcı ve diğg.(2016) ile Hazar ve diğ.(2018) üniversite öğrencilerinin spora yönelik tutumları üzerine yapmış oldukları çalışmada kadın öğrencilerin erkek öğrencilere kıyasla spora yönelik daha fazla eğilimlerinin olduğu ancak bu eğilimin istatistiksel olarak anlamlı olmadığı belirtilmektedir.

Atalı ve diğ. (2018) farklı fakültelerden spor ile ilgili ders alan öğrencilerin spora yönelik tutumları üzerine yapılmış olan çalışmaların da ise öğrencilerin spora yönelik tutumlarının psikososyal ve fiziksel gelişme alt boyutlarında kadın öğrencilerin puanlarının erkek öğrencilerin puanlarından; zihinsel gelişme alt boyutunda ve ölçek toplam puanlarında ise erkek öğrencilerin kadın öğrencilerden daha yüksek puan aldıkları belirlenmiştir.

Bu bulgular, mevcut çalışmanın sonucu ile örtüşmemektedir. Öğrenciler arasında anlamlı farkın çıkması, kadın ve erkek öğrencilerin spora yönelik benzer eğilim göstermemesinden kaynaklanmaktadır diyebiliriz. Ayrıca, benzer çalışmalarda anlamlı farkın çıkması, yapılan çalışmaların farklı gruplar üzerinde gerçekleştirilmesinden kaynaklanmaktadır. Farklı gruplardaki bireylerin spora bakış açısının farklı olması etkilidir. Sonuç olarak yapılan birçok çalışma incelendiğinde spora yönelik tutum puanlarının erkeklerin lehine daha yüksek bulunduğu söylenilebilir ve bu bulgular yapılan bu çalışmadaki spora yönelik tutum sonuçlarını destekler niteliktedir. Fakat araştırmamızın aksine Büyükdemira, Soyer ve Türkoğlu (2018) tarafından yapılmış olan çalışmada ortaöğretim öğrencilerinin cinsiyetlerine göre beden eğitimi ve spor dersine ilişkin tutumları arasındaki farklılıklar incelendiğinde, erkek öğrencilerin kadın öğrencilere göre daha olumlu tutum gösterdikleri bulunmuştur. 
Üniversite öğrencilerinin kendilerinin ve ailelerinin ekonomik gelir düzeyi değişkenine göre spora yönelik tutumlarına bakıldığında, öğrencilerin kendilerinin ve ailelerinin ekonomik gelir durumlarına göre spora yönelik tutumları arasında yapılan test sonucunda $f$ değeri 13,998 bulunmuştur. $\mathrm{Bu}$ sonuç 0,05 düzeyinde anlamlı bir farkın olduğunu ortaya koymuş bulunmaktadır. Farklılığın kaynağını anlamak için test yapmadan önce, varyans eşitliği hipotezi test edilmiştir. Levene testi sonucunda $(p>0,05)$ varyansların eşit olduğu sonucu çıkmıştır. Bu nedenle Post-hoc testlerinden Tukey testi uygulanmıştır. Bu testin sonucunda, 05 anlamlılık düzeyinde; en düşük, düşük ve orta gelir düzeyine sahip öğrenciler arasında anlamlı bir fark olmadığı görülmüştür ( $>0,05)$. Fakat yüksek ve en yüksek gelir düzeyine sahip öğrencilerin arasında da anlamlı bir fark görülmemiştir. Buna karşın orta ve altı gelir düzeyine sahip öğrencilerin yüksek ve üzeri gelire sahip ögrencilerden sportif tutum açısından farklılaştığı görülmektedir.

Yanık ve Çamlıyer, (2015) yapmış oldukları araştırmada öğrencilerin aile gelir düzeyine göre beden eğitimi dersine ilişkin tutum ölçeği puan ortalamaları incelendiğinde gruplar arasında istatistiksel olarak anlamlı bir fark görülmemiştir. Ancak gelir düzeyi azaldıkça öğrencilerin beden eğitimi dersine yönelik tutum puanı ortalamasının yükseldiği belirlenmiştir. Bu sonuç mevcut araştırmadaki sonuç ile paralellik göstermektedir. Diğer yandan üniversite öğrencileri üzerine yapılan bir araştırmada aylık aile gelir düzeyi orta seviyede olanların düşük ve yüksek olanlara göre beden eğitimi ve spora yönelik tutumlarının daha iyi düzeyde olduğu saptanmıştır (Yıldız ve ark, 2017).

Aynı çalışmada Yıldız ve ark, (2017) spor yapmayan üniversite öğrencilerinin spora yönelik tutumlarının spor yapanlardan daha yüksek olduğunu saptamıştır. Bu çalışmanın aksine Güllü ve ark, (2016) aktif spor yapanların aktif spor yapmayanlara göre spora yönelik tutumlarının anlamlı şekilde daha yüksek olduğunu tespit etmiştir. Ortaokul öğrencileri üzerine yapılan bir araştırmada raket sporu yapan öğrencilerin spora yönelik tutumları takım sporu ve diğer sporları yapanlara göre daha yüksek olduğu görülmüştür (Güllü ve ark, 2016).

Doğu Marmara bölgesinde yer alan beş devlet üniversitesinde (Kocaeli Üniversitesi, Sakarya Üniversitesi, Düzce Üniversitesi, Bolu Abant İzzet Baysal Üniversitesi ve Yalova Üniversitesi) öğrenim görmekte olan 933 üniversite öğrencisinin spora dair tutumlarının yaş, eğitim düzeyi, gelir düzeyi ve gelir düzeyi memnuniyeti, sporu tek başına yeterli bir gelir olarak görme durumu, değişkenleri açısından farklılaşıp farklılaşmadığı incelenmiştir fakat değişkenler arasında anlamlı bir farklılık bulunamamıştır $(\mathrm{p}>0,05)$. Spora yönelik tutum benlik saygısını negatif yönde anlamlı düzeyde, etkilememiştir. Yapılan araştırmada öğrencilerinin yaş değişkenine göre spora yönelik tutum puanlarına bakıldığında öğrencilerin yaşlarına göre spor yönelik tutumları arasında anlamlı bir farklılığın olmadığ1 görülmüştür ( $>>0,05)$. Bu sonucu destekler nitelikte Türkmen ve ark (2016) tarafından Bartın Üniversitesi İslami İlimler Fakültesi ögrencilerine yönelik yapılan spor tutumu çalışmasında öğrencilerin yaş ile spora yönelik tutumları arasında anlamlı farklılık görülmemektedir.

Tatar ve Kuru (2009) 20-40 yaş arası çalışan ve çalışmayan kadınların spor yapmalarını etkileyen bazı faktörlerin incelenmesi (Sivas il merkezi örneği) çalışmasında araştırmaya katılan kadınların spor yapmalarında yaş önemli bir faktör değildir şeklindedir. Bu çalışmalar mevcut çalışmanın sonucu ile benzerlik göstermektedir. Fakat Kangalgil ve diğ. (2006) tarafından yapılan çalışmada ise öğrencilerin yaşları büyüdükçe beden eğitimi ve spora karşı tutum puanlarının arttığ gözlenmiştir.

Sporun belirlenen hedeflerine ulaşabilmesi için öğrenciler tarafından sporun sevilmesi ve öneminin anlaşılması oldukça önemlidir. Sporun istenen hedeflerine ulaşabilmesi gençlerin spora yönelik tutumları ile yakından ilişkilidir (Başer, 2009). Spora yönelik tutumu olumlu olan birey, daha istek ve arzu ile spora yönelmekteyken, tersi durumda birey spordan uzaklaşabilmektedir. Gençlerin sahip oldukları kişisel yetenekleri ve sportif etkinlikler dahilinde ortaya koydukları hareketler gençlerin spora karşı tutumlarını belirlemektedir. Öğrenin; daha önce jimnastik hareketi yapmamış 
olan bir birey bu hareketi sistemli ve hedefine uyacak bir biçimde yapamayabilecektir. Buna ek olarak gencin söz konusu hareketi ortaya koyarken sakatlanma ihtimali de mevcuttur. Bu durum bireyin diğer spor hareketlerinde jimnastik sporuna özgü hareketlerden çekinmesine, jimnastik sporuna özgü hareketleri sırasında karşılaştığı olumsuz durumları hatırlamasına ve spora karşı olumsuz tutumlar geliştirmesine sebep olmaktadır. Bu olumsuz durumlar karşısında bireyin jimnastik sporuna özgü hareketlerine ve spora karşı olumsuz tutumlar ortaya koyması olası bir neticedir (Aras, 2013). Her birey yaşadığı olumsuzluklar karşısında kendince bir savunma mekanizması geliştirir. Yaptığı sportif hareketler ile yaşayacağı bir veya birden fazla olumsuzluk da bireyin spordan uzaklaşmasına sebep olacak bir tutum geliştirmesine neden olacaktır. Spora karş1 olumsuz tutumu olan öğrencinin derse karşı olan ilgisi azalmakta ve öğrenci derse girmeme yoluna bile gidebilmektedir. Öğrencilerin derse verdikleri önemin azalması da dersin işlenişini ve etkinliğini düşürmektedir. $\mathrm{Bu}$ açıdan bakıldığında spora karşı olan tutumun öğrenim etkinliklerinin başarılı olması konusunda önemli bir unsur olduğunu söylemek mümkündür (Çelik ve Pulur, 2011).

Sonuç olarak, mesleki olgunlaşma ve sosyal hayata hazırlanma dönemi olarak anılan üniversite hayatı, yalnızca akademik başarıya odaklı bir yaşam süreci olarak görülmemelidir.

\section{Kaynakça}

Aras, Ö. (2013). İlköğretim Kurumları İkinci Kademede Öğrenim Gören Öğrenci ve Görev Yapan Beden Eğitimi Öğretmenlerinin Beden Eğitimi Dersine Yönelik Görüş ve Tutumlarının İncelenmesi (Kars İli Örneği). Yayımlanmamış Yüksek Lisans Tezi). Gazi Üniversitesi/Eğitim Bilimleri Enstitüsü, Ankara.

Ajzen, I. (2001). Nature and Operation of Attitudes. Annual Review of Psychology, 52(1), 27-58.

Aşçı, F. H. (1999). Benlik Kavramı ve Spor. Spor Psikolojisi Kursu. P Bayar (Der), Bağırgan Yayınevi. Ankara. s.37-39.

Çelik, Z. ve Pulur, A. (2011). Ortaöğretim Öğrencilerinin Beden Eğitimi ve Spora İlişkin Tutumları, VAN/YYÜ Eğitim Fakültesi Dergisi Özel Sayısı, 115-121.

Güllü, M., Güçlü, M. ve Arslan, C. (2009). Ortaöğretim Öğrencilerinin Beden Eğitimi Dersine İlişkin Tutumlarının İncelenmesi. E-Journal of New World Sciences Academy, 4(4), 273-278.

Güllü, M., Cengiz Ş. Ş. ve Öztaşyonar, Y. (2016). Ortaokul Öğrencilerin Beden Eğitimi ve Spor Dersine İlişkin Tutumlarının Bazı Değişkenlere Göre İncelenmesi (Şanlıurfa İli Örneği). Gaziantep Üniversitesi Spor Bilimleri Dergisi. 1(2). 49-61.

Gün, E. (2006). Spor Yapanlarda Ve Spor Yapmayan Ergenlerde Benlik Saygısı. Yüksek Lisans Tezi, Çukurova Üniversitesi Sağlık Bilimler Enstitüsü, Adana.

Gerrig, R. J., Zimbardo, P. G. ve Sart, G. (2013). Psikoloji ve Yaşam: Psikolojiye Giriş. Nobel Yayınları, Ankara.

Çetin, M. (2007). Ortaöğretim Öğrencilerinin Beden Eğitimi ve Spora İlişkin Tutumlarının Karşılaştırılması (Kırşehir İl Örneği). Yayımlanmamış Yüksek Lisans Tezi. Gazi Üniversitesi Eğitim Bilimleri Enstitüsü, Beden Eğitimi ve Spor Öğretmenliği Bilim Dalı.

İçten, B., Koruç, Z. ve Kocaeski, Z. (2006). 6 Haftalık Egzersiz Öncesi ve Sonrası 12-15 Yaş Aralığındaki Çocukların Benlik Saygısındaki Değişim. 9. Uluslar Arası Spor Bilimleri Kongresi, Muğla. (2006).

Karaman, Ç., Son, M., Bayazıt, B., Dinçer, Ö. ve Çolak, E. (2012) Spor Yapan ve Yapmayan 10-12 Yaş Grubu Çocuklarda Benlik Saygısının İncelenmesi. I. Rekreasyon Araştırmaları Kongresi: 431 - 438, 12 - 15 Nisan 2012, Kemer, Antalya, ISBN: 978-605-5437-79-4 
Karasar, N. (2009), Bilimsel Araştırma Yöntemleri, Nobel Yayınları, Ankara.

Koca, C. ve Aşçı, H. (2004). Atletik Yeterlik Düzeyi ve Cinsiyetin Beden Eğitimine Yönelik Tutum Üzerine Etkisi. Gazi Beden Eğitimi ve Spor Bilimleri Dergisi, 9(1), 15-24.

Taşğın, Ö. ve Tekin, M. (2009). Çeşitli Değişkenlere Göre İlköğretim ve Orta Öğretim Kurumlarında Öğrenim Gören Öğrencilerin Beden Eğitimi ve Spor Dersine İlişkin Tutum ve Görüşleri. Kastamonu Eğitim Dergisi, 17(2), 457-466.

Varol, R., Varol, S. ve Türkmen, M. (2017). Bartın Üniversitesinde Öğrenim Gören Öğrencilerin Spora Yönelik Tutumlarının Belirlenmesi. Uluslararası Kültürel ve Sosyal Araştırmalar Dergisi (UKSAD), 3(2), 316-329.

Videbeck, S. L. (2001). Psychiatric Mental Health Nursing. Lippincott, Pp:8-11.

Şentürk, E. Ş. (2014). Spora Yönelik Tutum Ölçeği: Geliştirilmesi, Geçerliliği ve Güvenirliği, $C B \ddot{U}$ Beden Eğitimi ve Spor Bilimleri Dergisi, 7(2), 8-18.

Şişko, M. ve Demirhan, G. (2002). İlköğretim Okulları Ve Liselerde Öğrenim Gören Kız Ve Erkek Öğrencilerin Beden Eğitimi Spor Dersine İlişkin Tutumları, Hacettepe Üniversitesi Eğitim Fakültesi Dergisi, (23), 205-210.

Oktan, V. ve Şahin, M. (2010). Kız Ergenlerde Beden İmajı ile Benlik Saygısı Arasındaki İlişkinin İncelenmesi. Uluslar Arası İnsan Bilimleri Dergisi, 7(2), 543-556.

Orth, U. ve Robins, R.W. (2015) The Development of Self-Esteem. Current Directions In Psychological Science, 23 (5),381-387.

Weinberg, R.S. ve Gould, D. (2007). Foundations of Sport and Exercise Psychology. Human Kinetics Publishers, Champaign.

Yanik, M. ve Çamliyer, H. (2015). Ortaöğretim 9. Sınıf Öğrencilerinin Beden Eğitimi ve Spora İlişkin Tutumları İle Okula Yabancılaşma Düzeyleri Arasındaki İlişkinin Belirlenmesi. Uluslararast Spor Egzersiz ve Antrenman Bilimi Dergisi, 1(1), 9-19.

Yıldız, A. B., Arı, Ç. ve Yılmaz, B. (2017). Üniversite Öğrencilerinin Spora Yönelik Tutumlarının İncelenmesi (Ankara Yıldırım Beyazıt Üniversitesi Örneği). Muş Alparslan Üniversitesi Uluslararast Spor Bilimleri Dergisi. 1(1). 35-45. 